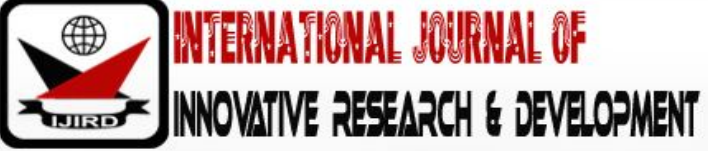

ISSN 2278 - 0211 (Online)

\section{Indigenous Forest Management and Subsistence Practices among the Guji Girja of Shakiso Woreda in Southern Ethiopia}

Negessa Mokona Tuma

Instructor, Department of Social Anthropology, Bule Hora University, Ethiopia

\begin{abstract}
:
This research explores the indigenous forest management, conservation system, institutions, in Guji Girja of Oromia Regional state, South Ethiopia since time immemorial. The study looks at the beliefs, values, ethics and taboos of indigenous knowledge in forest management and conservation practices. Additionally, traditional religion, ecological knowledge, social organization, different institutions at different level from gada institution to local household level for forest management and conservation, different trees utilization for different ceremonies and rituals and benefits from forest are identified as units for analysis. The research is qualitative in its approach. Relevant information to the research was collected from both primary and secondary sources. Many informants including women, men, forest agents and experts were interviewed. Moreover, observations, focus group discussions and case studies as well as both published and unpublished documents were examined. Results of this research show that Guji believe in Waqaa supernatural power / the creator/ who created heaven and earth, trees, grasses, mountains and rivers. They have deep ecological knowledge and strong relationship with their environment and got detail knowledge about the ecological benefits of trees or forests. They know forests attract rain, source of food for their livestock, place for agricultural activities, and sources of streams, rivers that can be used for drinking water by animals, birds and human beings. Guji culture has small and major indigenous institutions functioning for forest management and conservation. Smaller are individual house hold (Worra or Ardaa) and village (Olla). While major indigenous institutions are phratries categorized as Uraga, Hoku and Mati and Gada institution that having supreme power in Guji culture. Child bearing, collection of fuel wood, house construction, fetching water and most of household activities are practiced by women. On the other hand, men are highly engaged in hunting, herding, honey collection and agricultural activities agricultural activities. Rural economies within the woreda do not comprise a monolithic model of subsistence and commodity economics. Several types of traditional economies are practiced. The basic ones are farming and livestock rearing. There are also other subsistence economic activities such as hunting, gathering, honey production and mining. But nowadays, the indigenous forest management and conservation strategies are threatened by government policy and scientific forest management practices. As a result, there is a need for the revision and practical implementation of forest policies and proclamations in the context it can incorporate the livelihoods, interests and customary rules of the local community in order to ensure sustainable conservation of forest.
\end{abstract}

Keywords: Indigenous knowledge, management, forest, Guji Girja

\section{Background of the Guji Girja}

\subsection{Bio-physical and Socio-economic Condition}

Gujiland is mainly located in the southern part of Ethiopia in Oromia regional state, at large in the current Guji Zone and in the norther part of the Borena Zone. The Guji speak a southern dialect of Oromo language, which is categorized under lowland East Cushitic language of the Afro-Asiatic family.

In the current administrative arrangement of the country, the Guji exclusively inhabit in Oromia regional state. Namely, Shakiso, Wadera, Adola, Bore, Uraga, Qarcha, Bule Hora, Galana, Abbaya and Liben. Besides, they reside in Borena Zone, and around Bale Zone. Guji also reside in the southern Ethiopia Nations, Nationalities and Peoples' region According to Dejene (2007: 34), the Guji has a diverse ecology with wide ranging altitudes and climatic conditions. As a result, it has huge mineral potential and diverse plants and animal species. Its suitable for various crops and livestock types also varies across ecological differences. In the lowland areas, pastoralism dominates while the highland areas grow various cash crops, such as coffee, tobacco, and chat, and food crops, such as maize, finger millet, teff (Eragrostis teff L. Gramineae), and barley. Areas with altitudes above 1800m.a.s.l mostly grow these crops, while the lowland areas also grow them to a lesser extent but mainly practice pastoralism.

Guji mainly uses four sources of water. These are river (Galaana), deep wells (Tulaa), shallow wells (Adaadii) and pond (Haroo). Similarly, in Odo Shakiso woreda, even if they mostly use Hawata river, in some places, they are using different shallow wells (Adaadii), deep wells (Tulaa) and pond (Haroo) for human beings, livestock and as well as for mining purposes. 
Generally, water tenure system is open access and communally managed by identified family groups or villages just like that of forests.

The basic statistical report of the woreda further shows that the woreda's climatic condition is favorable for agriculture, and animal husbandry. The woreda is well known for cereals like (maize, wheat, barley and Eragrostic teff).

\subsection{A Short History of Guji Girja}

Guji are among the many groups of Oromo people in the nation. According to the elder's explanation, the origin of Guji people is believed to be from the area where they are settling now.

According to Dhadacha (2006: 14), the history of Guji people is traced back to one man called Gujo. As elders narrated, Gujo who was born and lived [around Adola], moved Northeastward with his three sons Urago, Matto, and Hoku, then settled in the area called Girja. After the lapse of very long period of time by raising cattle, the descendants of Gujo, moved in to the present area. This time, the Uraga group moved to the west, Matto to the north and Hoku to the south where they later on widened their abode by pushing the neighboring people. As time look to generations, the society to come was named after Gujo become Guji.

According to Taddesse (2000: 50), the Guji are confederation of three independent, but closely related, groups, phratries known as Uraga, Mati and Hoku. Traditionally, each section had its own territorial boundary and political leader in the form of aba gada 'an aged leader'. However, the three groups are interdependent: they regard each other as tied by blood relations, act together in case of war against neighboring groups, help each other during economic crisis, and conduct gada rituals together. Intermarriage is fairly common, and there are few cultural differences among them. Indeed, individuals or families from one group could move and settle in the other's territory.

Prior to integration in to Ethiopia nation, Guji were sovereign people, having distinguished boundaries and leaders. Their land was communally owned by clans and their economic practices have been based on animal husbandry and crop cultivation. According to (Hinnant 1977, cited in Dejene 2007: 34), significant changes have occurred since the 1950s, especially in the Mati, Hoku, territories. The former is reported to have expanded in to the latter's territory. In addition, intermixing of the three phratries (Mati, Hoku and Uraga) took place during the conquest and upheavals that followed it. Similar changes have occurred in the Guji territory in the south and they lost significant parts of the lands to Sidama and Gedeo in the north.

\subsection{Political and Social Organization of Guji Girja}

\subsubsection{Political Organization}

Guji political system is known as gada system. According to Taddesse (2000), gada is an age-grade system that divides the stages of life of individuals, from childhood to old age, in to a series of formal steps. There are thirteen such steps in contemporary Guji society. Transition ceremonies mark the passage from one stage to the next. Within each stage, activities and social roles are formally defined, both in terms of what is permitted and what is forbidden. The ideal length of time in one rank is eight years. In the past, the gada system assumed military, economic, legal and arbitration responsibilities. In recent years, however, the function of the gada system in Guji has been reduced to ritual activities.

Every confederacy does have aba gada (president). All aba gadas' were replaced by otheraba gadas in a peaceful and democratic way at the place called Futo. Since Futo site is found in the remote area (near Genale River), power (Baallii) transferring ceremony is currently taking place at Mie-bokko. In Guji gada system, there are five parties (Baallii's) from which aba gada is elected and assume power in every eight years. They are; Mudana, Dhallana, Robale, Halchisa and Harmufa.

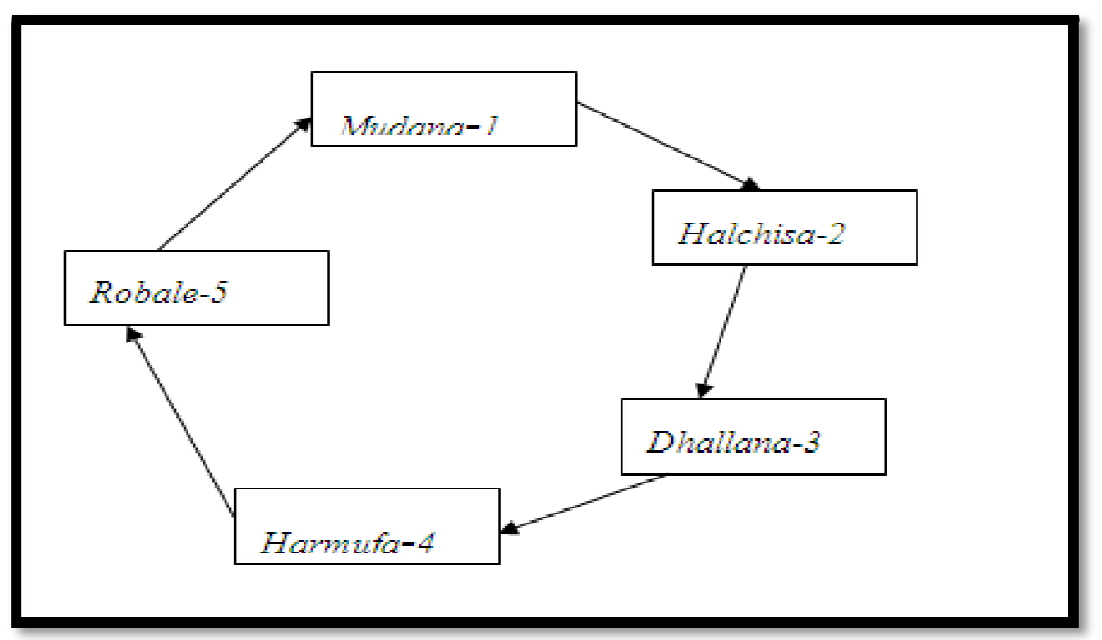

Figure 1: The Bali procession, Source: (Dhadacha 2006: 23)

During Baallii transferring ceremony, customary rules that have been used in the past years can be revised, if needed amended by executive bodies called Hayyu (Retired aba gada) and announced. The customary rules incorporate all aspect of the society; forest or trees rules, about marriage, animals, birds and nature. Each and every individual who are representatives of different Guji groups assemble at Mie-bokko (the political and cultural center) in every eight years. 
After the ceremony ends up, they return back to their home villages and inform the rest of the people, so that they practice the rules in their day to day life.

The following sketch shows the legislative structure of Guji gada system.

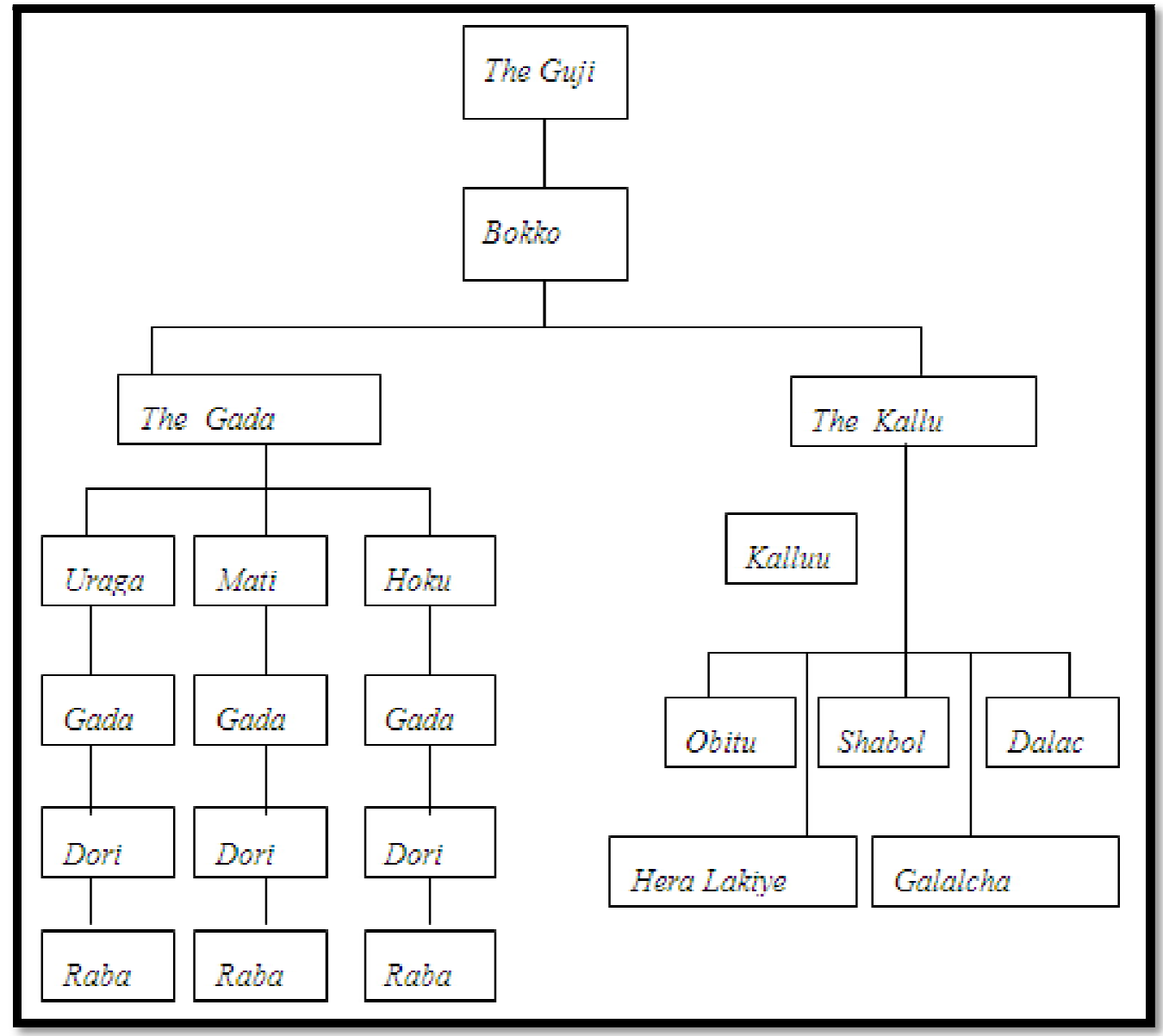

Figure 2: The Legislative Structure (Source: Dhadacha 2006:69)

\subsubsection{Social Organization}

\subsubsection{Kinship System}

Taddesse (2000) maintains that the traditional social organization of Guji society is dominated by moiety-clanlineage-family structure. There are two non-exogamous moieties, known as Kontoma and Darimu that cut across the three groups. Under these moieties, there are seven non-totemic and exogamous clans in Uraga and Hoku each, and three Mati. Each clan is divided into a variable number of segments called Mana, literally house', which in turn are divided in to a great number of patrilineages.

The following illustration shows how the Guji moiety system is divided. 


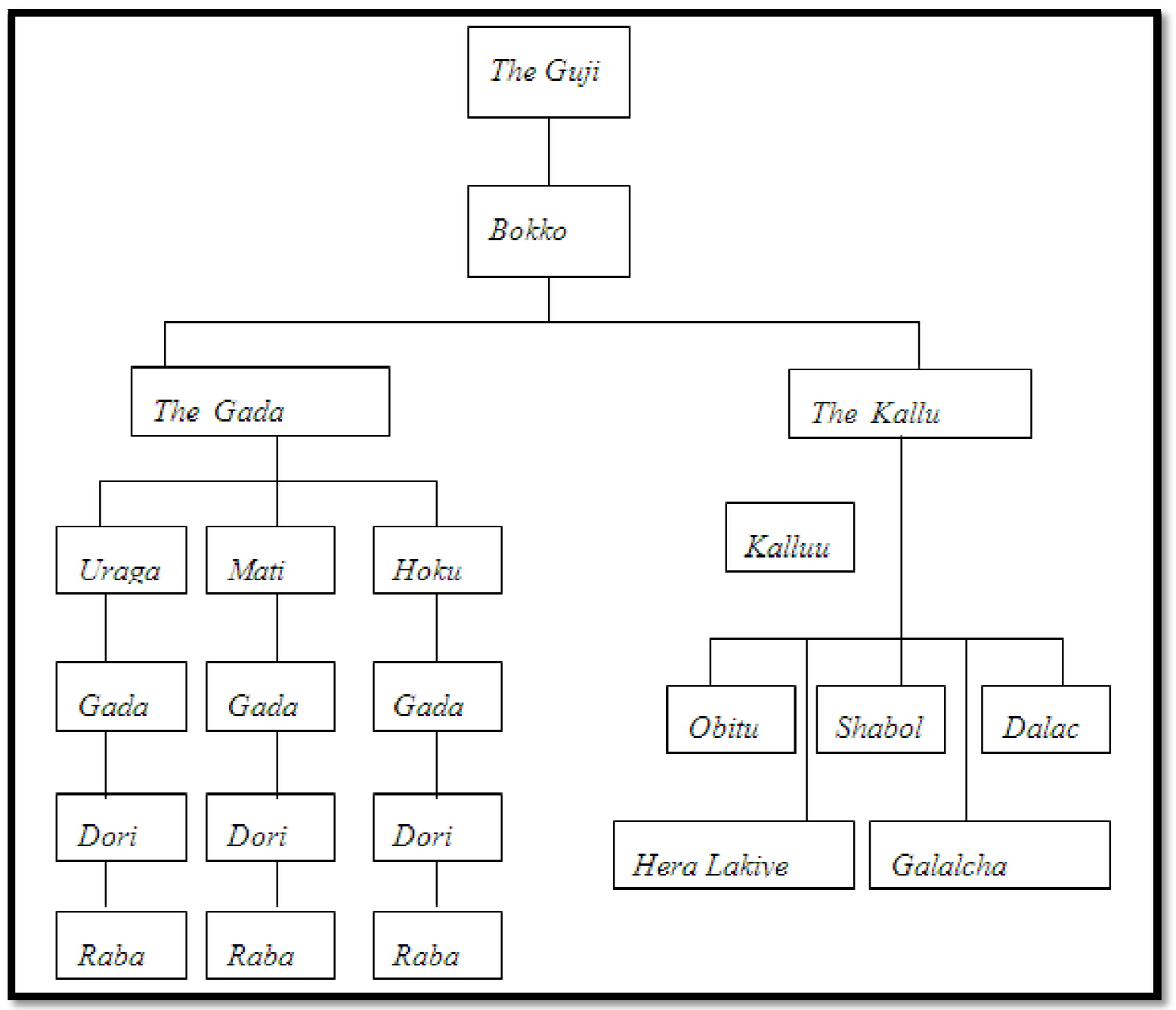

Figure 3: The Kontoma and Darimu Category of Three Tribes of the Southern Guji

Source: (Dhadacha 2006:20)

\subsubsection{Marriage and Family}

Marriage and family formation are one of the social organization mechanisms. In Guji culture, there are four kinds of marriages. These are Marriage at disposal of the family(Kadhaa), Marriage by mutual consent (Hawadii), Marriage by exclusive choice of the girl (Addibaana) and Marriage by exclusive choice of the man or Abduction (Buttaa).

According to Taddesse (2000), the Guji family is an extended patriarchal family. Marriage is based, in most cases, on self-selection and on arrangement between the families of the bridge and groom. Polygyny, primogeniture, patrilocal residence and levitant are some features of the Guji marriage and family system.

\section{Indigenous Knowledge System}

\subsection{Indigenous Religion}

Guji believe in Waqa, super natural power, the creator who created heaven and earth, trees, grasses, mountains and rivers. Guji religious practices are embedded in the gada system. Religious rituals and ceremonies (blessings and cursing) are mostly performed by Kalu.Kalu is the religious institution which is responsible for spiritual activities in Guji gada system. Indicating the origin of Guji religion (Hinnant, 1977, cited in Taddesse, 2000:141) writes that:

Historically, the central religious and social institution of the Guji and many other peoples in north east

Africa has been the gada system, which consists of a particularly, complex set of rules for ordering society and a rich cosmology that explains the power of the universe and also provides means for coping with events. The Guji gada system had, among other things, military, social and ritual rules which were important for controlling population increase and for preventing the environment from degradation.

There are different religious rituals in different places. Most of the time prayers are performed under trees, forest areas and around rivers. These ceremonies do have great contribution for forest management and conservation. Taddesse (2000:142) stated that, "... traditional Guji religion had important function in protecting the environment from degradation." Some big trees are considered as sacred and are used for prayers just like churches and mosques.

However, nowadays, the indigenous religion is under pressure from different external religions like Protestant Christianity and Islam. Kobolle Godana explained that: "Wonni aadaa teenna balleessaa jira, Qeesi fi Sheekii". This means it is priests and sheiks that are distracting our culture. They are converting specially the young generation by attracting them 
towards the new religion. Due to this, the new generation is about to abandon the indigenous religious practices and leaving them to the older generations.

In Guji culture, trees are considered as gift from God or Waqa to human beings to manage, conserve and use them properly. In addition, different prayers, marriage ceremonies, meetings, political, economic and other cultural activities are highly attached to trees. There is a customary rule that says Muki Woyyu meaning trees are sacred. Guji use different trees and herbs named, Mokonisa (Euphorbiaceae), Hadhessa (Rutaceae), Madhisisa, Kirkabata and Buki in prayer to prevent bad thing or accidents from happening (Bita gatatiisa). For instance, in case of Titita, the herb is tied to differently directed trees. Then, by passing under the tied Titita, they perform a preventive prayer called Huluka. Similarly, in case of Buki herb, they pray passing under two tips tied to different trees Buki saying:

Buqqii hadhoottuu tanaa,

Haadhaa nu baasi

Lubbuu nu "

Cubbuu nu "

Dhukkubaa nu "

Woraanaa nu "

The above Afaan Oromo version is translated as; let this bitter Buki prevent us from sorrow, death, sin, disease, and war. Buki herb is bitter in character. So, these all bad things are symbolized by this herb. That is why it is used for preventive prayers. There are different prayers to Waqa using trees. For instance, there is a saying used when different meetings are held under trees like Dhugo; "Waaqa dhugoo baddaa nu godhi, dhugaa nu dubbisi". This means let Waqa make us like Dhugo in the forests and help us to speak true. This tree is used here because the meaning of the name Dhugo by itself came from the word Dhugaa meaning true.

There is also a prayer related to Dambi (Ficus thommingii) tree; "Dambii dagalee nu godhi waan daga dhufee nubaasi". This means "let Waqa keep us together like tying Dambi and protect us from accidents". Dambi herb is mostly used for tying woods during house construction. It keeps a number of different woods together and makes a strong house. Here Dambi is symbolically used to represent unity.

A prayer related to Birbissa (Podocarpus falcatus) says: "Sitta dheenne Birbissa dhooggataa kana hantuu nurraa dhooggi". This prayer can be translated as; we come to you the old and resistant Birbissa; let you protect us from bad things. Here Birbissa tree is used to symbolically represent strength, resistance and long life. According to key informant Kobolle Godana, "Nowadays the young and adults are dying at early age, a case which had not happened during our ancestors. This is because they have committed sin on trees by cutting them down carelessly every time and in all places. But our ancestors died at old age because they respected trees."

Generally, from the above information, we can clearly understand how Guji relate the life span of individuals with the respect or disrespect they give to trees. Their ancestors lived long life because they respected trees, but the current generation is living shorter because they are committing sin and are therefore in opposition to Waqa. All the three major Guji groups or phratries (Uraga, Hoku and Mati) do have their own trees that are used for prayers. The trees grow at different geographical areas where the three phratries are settling. For instance, Miesa tree is found around low lands areas where Hoku group is inhabited, and Uraga and Mati who settled in high land areas have their own as well.

Accordingly, the Uraga group uses the tree called Uraga (Boraginaceae) and prays to Waqa in the following way: "Waaqa Uraagaa kanaa waan hantuu na fullaasi na horsiisi". This means "let Waqa of the Uraga tree protect me from bad things and help me to prosper". Uraga tree has certain characteristics: it is big, strong, and taller than many other trees. It symbolizes being strong and winner in different situations. That is the reason why it is selected for prayers. The Hoku group on its part uses Miesa tree for prays to Waqa. The prayer goes:

Waaqa Mi'eessa kanaa namati na mi'eessi

Sa'ati na mi'eessi

Intalati na mi'eessi

Kolbati na mi'eessi

The above Afaan Oromo version is translated as; let Waqa of the Miesa tree help me to be sweet with people, cow, and wife. The tree has different characteristics; it is strong, green even in dry season and the name Miesa itself means sweet. So, it symbolizes these things and that is why it is used in prayers.

The Mati group uses Uddessa(Verbenaceae) tree and prays to Waqa in the following way: "Waaqa Uddeessaa kanaa namaan na uddeessi, Sa'aan na uddeessi". This means "let Waqa of the Uddessa tree helps me to prosper and blessed with cows and children". Uddessa (Verbenaceae) tree has good flavor and strong in nature. Uddessa(Verbenaceae) is used in prayers to symbolize the mentioned characteristics.

Trees like Oda and Kilta are used for blessing a newly born baby, a newly born calf, married girl and others. As Dembele Elema explained:

\section{Latii daraari}

Horii banqaaqi

Hidda qilxaa (Odaa) te'i

The above Afaan Oromo version is translated as;

"let you grow, bloom, and flourish like Kilta or Oda tree". These trees are strong, ever green and serve as shade, house for animals and birds. It is used to symbolize the strength, and green characteristics.

Even if you are undertaking a long journey and forced to sleep somewhere in forest area or under trees, culturally it is advisable to sleep under trees like Woddessa (Cordia adryssinica), Oda, Uddessa (Verbenaceae), Dambi and Miesa. It is not 
good to sleep under any tree because it is believed that you may die. But if you sleep under these trees it is believed that you to live long.

\section{Regarding this issue, gada made the following declaration: \\ Yoo deentu muka jala buli \\ Yoo fuutu muka " " \\ Yoo godaantu muka jala qubadhu \\ The above Afaan Oromo version is translated as;}

"let you sleep under trees if you are on journey, on marriage, and when you settle in new place".

Finally, almost all of the religious rituals, prayers and ceremonies in Guji culture are performed using trees, undertaken under trees and highly related with trees or forests. When explaining the reason for using trees, my key informant, Budiso Goshesaid, "Waan abbootiin teenna itti dheetani ittiin le'aniifi mukoota kanaan waaqa kadhaanna". We pray using trees because our ancestors used to pray under them and lived long life.

\subsection{Ecological Knowledge}

The Guji have deep ecological knowledge and strong relationship with their environment. Explaining about the nature of tree aba gada Kobolle Godana who is 75 said:

Muka waaqati namaa kenne. Aka bu’aa jireenna keennaaf irraa buufannuuf akkasumas aka isa eennuuf.

Muki lubbuu qaba.Kana wonni beettuun hin lata, hin guddata, hin dullooma hin du'a.Yoo muranulle akka

namaa oo'ee lafa dhawa.Muki yennaa aduu gaaddisa nuuf keenna.Akkasumaan rooballe hin harkisa.Yoo

jala ciratanille midhaan dansaa namaa kenna. Bisaanti jalaa madda.Tanaafuu muki lubbuu teenna jechu'u.

The above Afaan Oromo version is translated as; trees are given from Waqa to human beings. So, we use trees and conserve them. Trees do have life. Because they grow, become old and die. If you cut trees they fall down shouting just like human beings. Trees are used as shades during dry season, attract rain, help to get good harvest if one cultivates under trees and they are sources of streams. So, trees are our life. From the above explanation we can understand that Guji have got detail knowledge about the ecological benefits of trees or forests. They know forests attract rain, source of food for their livestock, place for agricultural activities, and sources of streams, rivers that can be used for drinking water by animals, birds and human beings.

On the other hand, one of my key informants explained about why he is having big trees on his farm; "big trees are left on the farm because the leaves falling from trees are used as fertilizer and if there are no big trees on the farm, the farm will be washed away by erosion". Additionally, he stressed, if there were no forests, there would be no enough food, honey production, house construction, shade, water for our livestock and human beings. Even there would be no gold and tantalum mining activities because forests are sources of water and we use water to refine gold from soil.

Another key informant Sher if Wako explained the importance of forest by comparing the forest coverage in the past and present; "previously Korkoro area was covered by dense forest. Therefore, there was enough rainfall. But currently, because of deforestation, there is no enough rain in the area. As a result, there is no good harvest and the weather is hot, which is not comfortable for birds, animals and human beings.

Generally, based on the above information we can conclude that, Guji people have detail knowledge about the ecological benefits of trees or forests.

\section{Indigenous Forest Management Practices}

\subsection{Customary small Institutions for Forest Management}

\subsubsection{Basic Institutions}

In Guji culture, there are basic indigenous institutions functioning for forest management and conservation. They are individual house hold (Worra or Ardaa) and family groups (Dudda, Roga or Goro).

Compared to central government institutions, local institutions are considered better at providing rules related to access, harvesting, and management and provide a forum that can respond to conflicts quickly and cheaply (Varughese G.,1998) as cited in Zewdie 2009: 49).

\subsubsection{Individual Household (Ardaa or Worra)}

This is the smallest institution that is found at the grassroots level. This institution does have demarcated forest area where the members of a household are responsible to conserve and manage. Almost in every Guji household compounds, there are different trees and shrubs that are conserved by household members. Without permission of the household members, it is not allowed for outsiders to use different forest products.

On the other hand, there are individual households grazing lands that can only be used during dry season. In rainy season, livestock usually graze on fields. Except for some relative's livestock, grasses and trees inside pasture land are not allowed to outsiders.

Father, mother, children and other relatives living with a family are responsible to conserve the area. During my field work, I have observed that the Guji household surroundings are full of big trees when compared to immigrants living in area. Besides, the father or son from a household can have beehive (Hidhoo gaaguraa) in certain forest place that no any other person is allowed to cut trees and carelessly use forest products in that beehive surroundings. This is because it is believed that the area belongs to the owner of the beehive and even the area will be named by the person. This 
systematically sharing of responsibilities to conserve and mange forests helped the society to properly utilize forests and its products wisely and economically.

The owner of a beehive does have the right to use the forest and its product in the area, and also has the responsibility to protect and conserve it. If fire damages the forest or if the person cuts down big trees without genuine use, primarily he will be advised by his family and relatives. If he does not stop damaging the forest, the case will be referred to the upper class called phratry.

In order to influence the family so that they can resolve the problem by themselves, there is a saying:

Worra gowwaa dubbiin fira (Gosa) dhaxxi

Fira gowwaa dubbiin yaa'a dhaxxi

The above Afaan Oromo version is translated as; it is only foolish family that their case referred to phratries level or to aba gada level.

Generally, based on the above-mentioned information, household is one of the basic institutions that have been contributing to the management and conservation of forests in Guji area.

\subsubsection{Gender (Koorniyaa)}

Gender is the social construction rather than biological differences between male and female. Accordingly, indigenous knowledge and experiences on forest conservation and management are expected to be distributed among community members. Nowadays, even if there are some gender-based works in Guji culture, almost both women and men do have the same responsibility in their daily life activities like farming, house construction, livestock keeping and others.

But there are some special works given for women than men do not practice usually. For instance, child bearing, collection of fuel wood, house construction, fetching water and most of household activities are practiced by women. On the other hand, men are highly engaged in hunting, herding, honey collection and agricultural activities. In both cases, since the life of Guji people is highly attached to forest, both sexes do have detailed knowledge about forest and environmental conservation. There are different roots, leaves and stems of trees that are collected by Guji women. For instance, for the purpose of perfuming or Scent (Qayya), they consume trees and shrubs called Hadha-gobeya, Kodhi, Kundhi, Wato, Kadida- dalacha, Saffarra and Bolima.

Conversely, they use trees like Ejersa (Olea Africana), Dabaka and Badessa(Myrtaceae) as fumigation for milk preservation (Qorasuma). There are also different trees, shrubs and herbs used by Guji women for different purposes. Gagama (Oleaceae) tree is used as food for calves, milk preservation, and fire wood; Hophi (Apocynaceae) used for calf house construction; Dhokonu and Motoqoma (Ulmaceae) used for calf feed; Tilo for fire wood, Hophi (Apocynaceae) and Dhirri used for the construction of scent house (Bola Qayya). Dhokonu tree is used for construction of bed room (Kolloo). Birbissa (Podocarpaceae) tree is used for house construction and Harange used for washing cloth (soap).

Generally, there are different gender based and forest related activities in Guji culture. Most of wild food collections and house related works which are not physical activities are practiced by women. Whereas the physical works are mostly practiced by men. Both sexes involve in forest-based activities that contributed a lot for forest management and conservation and helped them to have detail knowledge about the forest for their life.

\subsubsection{Village (Ollaa)}

This indigenous institution which is bigger than household and consists only a single household. A village consists of more than two households that are from different or related family. Sometimes it is the combination of extended families. They relatively settle in a wider forest area that usually outsiders are not allowed to graze, cut down trees, or use forest products without the group permission.

Village groups' forest conservation not only prevents outsiders, it also includes the insider's proper use of forests. For instance, if someone from the family is not using forest properly, deforest without an agreement of the members, cuts down big tree without genuine reason, he/ she will be advised by group members at family level. If it is not possible to resolve the issue at this stage, the case will be referred to the next upper level called phratries or group. Both in households and village group cases, they use grazing or pasture lands during dry seasons. But in rainy seasons, they mostly use to graze their livestock in commonly- managed forest areas and fields.

Generally, these two basic institutions have been significantly functioning in managing and conserving biodiversity in the area.

\subsection{Functions of Major indigenous Institutions in Forest Management and Conservation}

\subsubsection{Phratries / Groups}

The Guji phratries are categorized as Uraga, Hoku and Mati. Under each group, except Mati that have three, there are seven non-totemic and exogamous clans. The Uraga group has Galalcha, Darartu, Gola, Sarbortu, Wajitu, Agantu, and Halo clans.

Phratry is the next upper stage above village groups. This stage also plays great role in forest management and conservation as well as resolving different problems that could not be resolved at the household and village group levels. For instance, if someone cut down trees for unidentified purpose or deforested for agricultural activities without permission, the case is investigated by household or village groups. If it is not resolved, it will be referred to phratry stage. Sometime, at this state, there could be punishment if the person does not stop his destructive activities. The lineage has got the power to beat the person by laying him on green grass under big trees. In this case, every member of that specific group is obligated to participate because it is believed that others get lesson from the punishment. The punishment ritual 
includes slaughtering an ox from the person's cattle and eating in group. Now, the beaten person's body will be massaged by butter so that the person gets relief. Then after, it is hoped that the person will not repeat the same destruction on trees. If in case he is seen doing the same activity, the case will be referred to the last supreme power level, gada stage.

Finally, the phratry institution has contributed a lot for generations in managing, conserving and supporting the sustainable utilization of forest resources in the area.

\subsubsection{Gada Institution}

Gada institution has the supreme power in Guji culture. This institution functions in managing and conserving forest in addition to administering the political, economic, social and cultural aspects of the people. This institution is equally functioning in all the three Guji phratries. It is this institution that makes and enforces customary rules and regulations at law making center (Mie-bokko). The rules are prepared by the previous aba gada (Yuba). Law making processes take around twenty-seven (27) days. The duration is based on the twenty-seven ritual days (Ayyaanota) of Guji culture.

According to the explanation given by the elder Yohanes Gambela and one of the current Yuba, Jaba Kurundhe:

Guyyoota seera kana tumanu digdamii torban kana keessatti yuubota, gadoota fi hayyooti waan daraaraatii fi aanan malee bishaan hin dhugamu.Sababiin isaas yoo bishaan dhugame, seerattu bishaan te'a, akka bishaanii laafa ykn qadhata jedhamee waan amanamuuf.Akkasumas seera tumiisaa fi labsiisi barii ganama adoo aduun hin bayin irraa jalaqabee haga aduun utubaa irraa hin dabin qofa labsamee dhaabbata.Sababi isaa seerri yennaa aduun utubaa irraa dadde bayee labsame hin daba yokaan hin dhaabbatu jedhamee waan amanamuuf.

The message in the quotation above can be translated as: Within these twenty-seven laws making and announcing days, the Yuba, Hayyu, and aba gada will not drink water except milk and drinks made from plants. This is because it is believed that if water is consumed, the laws can be weak like water. Additionally, laws are made and announced starting from early sun rises up to the mid-day only. This is because the laws and announcements made after the sun shifted from straightly shining from sky towards the west direction are believed to be corrupted or wrongly used. Generally, Guji sit under trees to make customary rules and use drinking made form plants that are used during twentyseven days of law making days. This can clearly show us how they give great cultural values for forests and forest products. Most of the Guji customary laws are made and ratified by the Guji participants at Mie-bokko. As a result, taking the announcements, they return to their home villages and inform the rest of the people, so that they can practice these rules in their every day to day life. Usually the laws are enforced and implemented by abbaa gadaa in the areas.

The current forest management strategy known as Participatory Forest Management (PFM) is an old fashion. They have been practicing it for generations. All Guji born individuals have enough awareness about the benefits of forest conservation for their existence. This life experience taught and helped them to conserve forest for a long period of time without external body's guidance. For instance, if big tree is found cut down, any person observing it will try to investigate the person who did so. If the person is known, he or she will be advised to use it for some purpose and warn not to repeat such a mistake. So, this shows that every individual has the right and responsibility to use or enforce the customary rules concerning forest in every time and place.

In Guji culture, among the different customary rules announced by Yuba at law making center, every year, there are rules concerning forests, especially big trees. This explained by the current Yuba of Hoku group Jabo Kundhushe:

Woyyuun angatti waaqaa lafaa santi seera

Itti aansee haadhaa abba'a ti woyyuu santi seera

Itti aansee gadaan woyyuu santi seera

Itti aansee muki woyyuu santi seera

Muka mudhisa jiru hin muranu santi seeraa

Muka yennaa muranu damee irraa hin qululchanu santi seeraa

Itti aansee maddi woyyuu santi seera

Itti aansee malkaan woyyuu santi seera

Itti aansee karaan woyyuu santi seera

Itti aansee haati Sodda'a woyyuu santi seera

The above Afaan Oromo version is translated as; Heaven and earth are the primary sacred things, this is our rule. Secondly, father and mother are sacred, this is our rule. Thirdly, gada is sacred, this is our rule. Fourthly, trees are sacred, this is our rule.Trees on the road side are not cut downWhen trees are cut down, it should not be from the root. Fifth, Stream is sacred, this is our rule.Sixth, river bank is sacred, this is our rule. Seventh, roads are sacred, this is our rule. Eighth, wife's mother is sacred, this is our rule.

Generally, in the Guji customary rules, trees are classified as one of the sacred things among others mentioned above. This clearly shows how trees are given cultural values and respects. This has been contributing a lot for generations in order to manage, properly utilize, protect and conserve forests and its products in the area.

The Debele of the gada institution serves to enforces and follow up the implementation of the rules at local level. At this stage different cases that could not be resolved at households, village groups will be resolved at gada institution. In this case, the person will be advised for the last time. If he is not accepting the advice, he will be beaten again and pays an ox or cow (Duddaa-goronsa). Finally, if he does not stop his destructive actions, he will be killed by Debele (Gumaa buusuu). Gumaa buusuu means killing the person. But currently, the practice of killing a person does not exist. Killing a person because of destruction he made on trees can clearly imply how Guji give big values for trees than one's life. The following structure shows the judiciary structure of Guji gada system. 


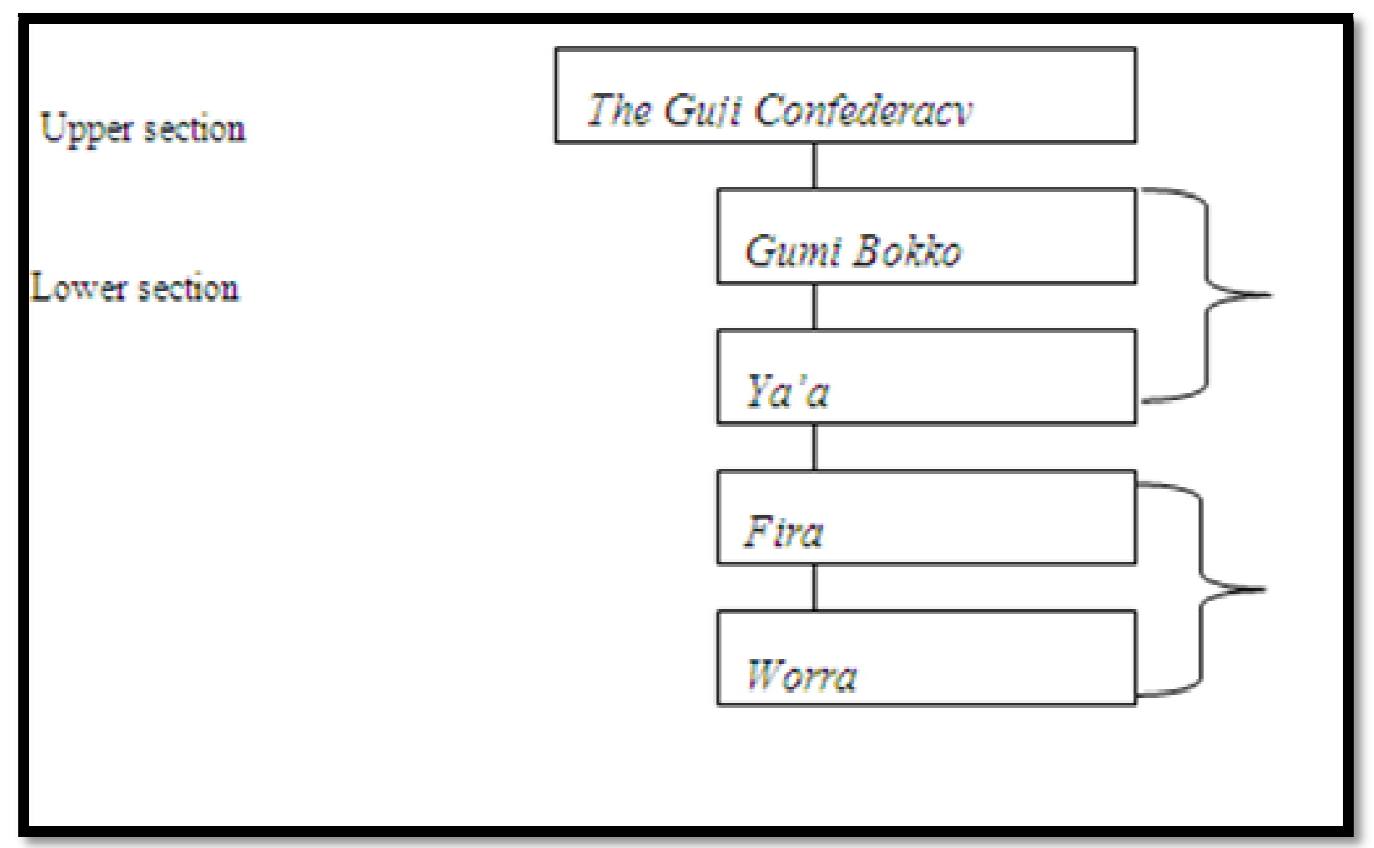

Figure 4: Judiciary Structure, Source: (Dhadacha 2006: 76)

Generally, different forest management and conservation related measures taken by different institutions range from advice - beating - bull offering - killing. The measures are taken because the life of Guji is highly dependent on forests and their products. Disregarding the contribution of the indigenous institution has resulted in the damage for forest areas. Therefore, the best solution for the sustainable forest management and conservation is to harmonize and apply both the indigenous and scientific forest management systems together.

\section{Indigenous Subsistence Economic Practice}

Rural economies within the woreda do not comprise a monolithic model of subsistence and commodity economics. Several types of traditional economies are practiced. The basic ones are farming and livestock rearing. There are other activities such as hunting, gathering, honey production and mining are the major subsistence activities in the area. Most of these activities are practiced inside or around forest areas. Since all these activities depend on forest, in one way or another, they do have great impact on forest resources.

\subsection{Farm Activities and Forest Conservation}

Farming is an activity practiced mostly inside or around forest area. This is because forest areas do have fertile soil that can help to get good harvest. There are different crops like wheat, maize, barley and teff that are cultivated and consumed. Decomposed leaves under big trees are comfortable environment for the production of these crops. It is because of this that people in the area prefer to produce these crops. Most of the traditional tools employed for the production of these crops are small axe slashes and hoe. But currently, people are using drawn pair of oxen. In this case, different materials mentioned under farming tools are used.

While performing these farming activities, Guji do have forest conservation strategies. Primarily, while preparing farm land, they do not cut down big trees except shrubs and herbs. This shows how they give respect to big trees. Even after shrubs and herbs are cleared, burning is performed carefully in the way that it does not harm other forest area. Before burning, the farmer clears the surrounding dead leaves so that fire cannot pass to forest area. The direction of the wind should be identified. If there is high wind blow, the farmer will change the burning schedule to night or morning time. This is because, there is no high temperature that could increase the power of fire and make it unmanageable. Burning is done in mid-day if and only if there is no high wind and the farmer thinks he can manage the fire.

\subsubsection{Case-1}

Dulacha Ware is a farmer living in Odo Shakiso Woreda. Explaining about forest conservation practices in relation to subsistence economy he narrated the following:

I cultivate different crops like wheat, maize and barley. I use traditional tools like small axe, slashes and hoe. I am conserving big trees around my farm because I know they attract rain so that I can have good harvest. Leaves falling from trees are used as fertilizer. But nowadays we can observe big trees being cut down by individuals. I do not cut down big tree unless it is for beehive making. I mostly use branches of trees to make farming tools because if I use branches, I can use one tree for long years. In our culture, big trees are symbolized as an aged person and cutting them down without genuine use is considered as killing. 


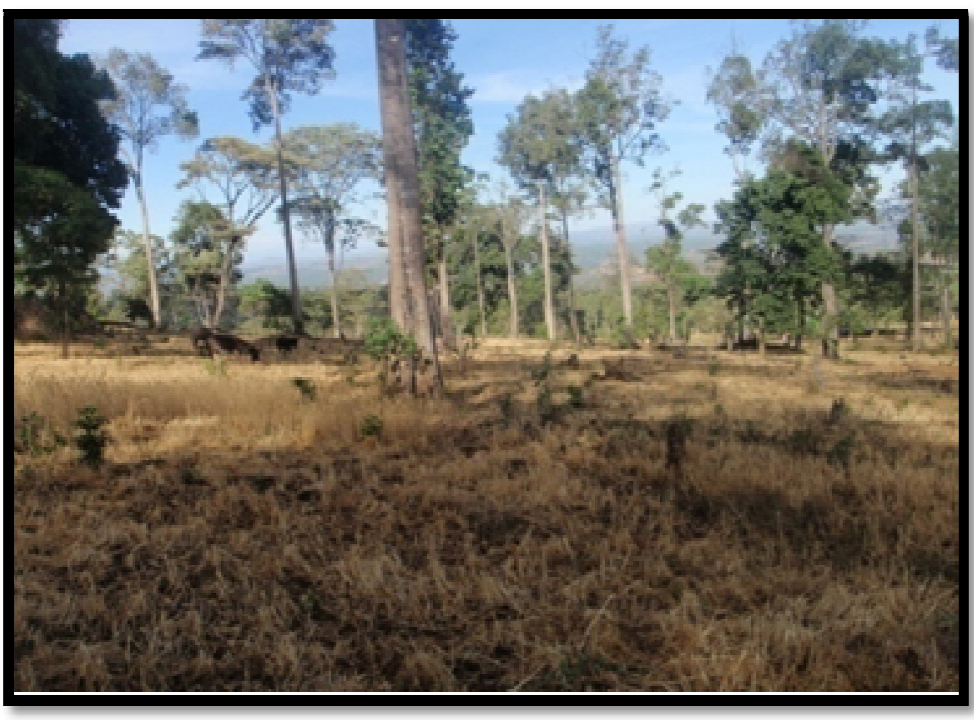

Figure 5: Farming Inside Forests

As one can understand from the above narration, big trees are not cut down during farm land preparation because of cultural values attached to them, their ability to attract rain and help to get good harvest. So, all farming activities are performed carefully in the way that they do not damage big trees or forest around a farm. On the other hand, Guji people use the old livestock house areas (Moonaa dullattii) for farmland. This is because it is more fertile than other places. This played a great role in decreasing the deforestation rate of forest areas for farming activities. Additionally, fallow system that has been practiced in the area also contributed a lot for biodiversity conservation.

Generally, it is in economical and wise utilization of forest resources that Guji perform farming activities in line with forest management and conservation.

\subsection{Livestock Rearing and Forest Conservation}

Livestock rearing is one of the major economic activities of the Guji that highly dependent on forest. They own; cattle, sheep, goats, donkey, mules and horses. The meat, milk and other products of the cattle, sheep and goats are consumed at household level and serve as source of additional income.

Guji have best indigenous forest management and conservation strategies in line with livestock reproduction. One of the strategies is pasture land management that is kept during rainy season and to be used in dry season. This is mostly done when farmers are relatively fixed in specific place for a long period of time. In this case, livestock are not allowed to enter to pasture land except in dry season. This played great role for biodiversity management and conservation without being continuously utilized and damaged.

Even in dry season if grasses inside pasture land are totally consumed because of over utilization, trees leave inside or outside the pasture land can be used as fodder. This is done in the way that it does not harm the trees. This means only branches or leave are used without cutting the main part of a tree. This is because they know that the branches of a tree can be used for many years. But if the main part of a tree is cut down, there is only one chance of using a tree.

According to the informants, there is a seasonal and directional movement of livestock grazing or transhumance (Godaansa). It is another strategy used both to secure enough amount of food for their livestock in different seasons and for forest conservation. This is shifting utilization of highland and lowland resources. They move towards lowland direction in rainy season in order to properly consume grasses, leaves and water that can be obtained during the season. On the other hand, the same resources in highland areas will be kept for hardship and dry season. This wisely shifting utilization of resources played a great role in keeping the balance between livestock breeding and forest conservation.

Explaining about the systematic and balanced utilization of forest conservation and livestock breeding, one of my best informants narrated as the following:

\subsubsection{Case-2}

I am a farmer. I have two wives and nine children. One of my wives is living in low land area around Saba Boru where pastoralism is the main source of economy and the second wife is living in Shakiso area where mixed farming is practiced. I have a number of cattle in both areas and small farm place around Shakiso town. Majority of my cattle do move between these two sites based on the seasons. I move my cattle to lowlands during rainy season and to high lands in dry season. It is by this periodical movement that I keep the balances between cattle raring and utilization of forest resources. As we can understand from the above narration, shifting utilization of forest resources in livestock reproduction has served to conserve and use forest in sustainable way. Indigenous knowledge for systematic and wise utilization of natural resources has contributed a lot for sustainable use of biodiversity and conservation in the area. 


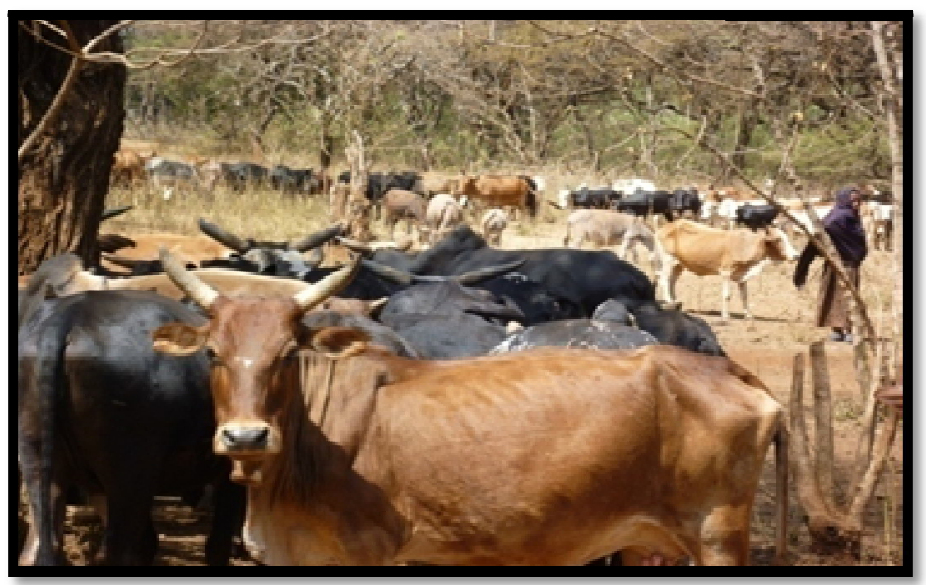

Figure 6: Cattles

In Guji culture, there are different songs related to livestock rearing and trees. Mostly the songs are made using culturally valued trees. For instance, if a cow or woman delivered, they say;

Uddeessaan baqee horibboo

Mi'eessaan latee horibboo

Uddoon daraaree horibboo

Uddessa has bloomed let you be blessed

Miesa has grown let you be blessed

Uddo has flower let you be blessed

The existence of Guji livestock is dependent on forests. So, they give due attention to trees or forests management and conservation.

\subsection{Honey Production and Forest Conservation}

Honey is one of the forest products. Flowers of trees are sources of honey. In Guji, honey is used as medicine, food, source of income and used in all cultural rituals and ceremonies. For instance, honey is used in blessings and prayers by aba gada in marriage ceremony, in the prayer for husband and wife that could not give birth.

Traditional beehive is prepared from big trees. But big trees are not cut down usually in Guji culture. In order to give solution for this problem most of the time beehive is made from big trees that become old and fall down by wind. This is done to conserve forest, save trees from being deforested in every beehive making activities and help to use trees economically.

In Guji area in general and Shakiso woreda in particular, there are different trees used for making beehives. They areBirbirsa, Woddessa, Guduba, Harrattu, and Wolena. If big trees are cut down for the purpose of beehives making, trees should not be totally cut down from the root, some part of the trees should be left out to help it grow again and so that a single tree can be used for long period of time. But in Mecha areas of Oromia, beehives are not made trees. They are made from shrubs.

After beehive is prepared and put on a tree, in addition to honey production, these do have great contribution for forest management and conservation. Because in Guji culture, if someone put his beehive in certain forest area, that forest area is named by that person (Hidhoo ebeluu). The person will take the responsibility of that forest area. Outsiders are not allowed to use the forest and its products in the area without the recognition of the person. Another forest conservation activity related to honey production is performed during honey harvesting. Since honey harvesting needs fire, it is done in the way that it does not damage forests. Smoke is used to control bees so that they do not bite or harm the honey collector. A minor mistake in using fire while harvesting honey will result in great damage of forest area.

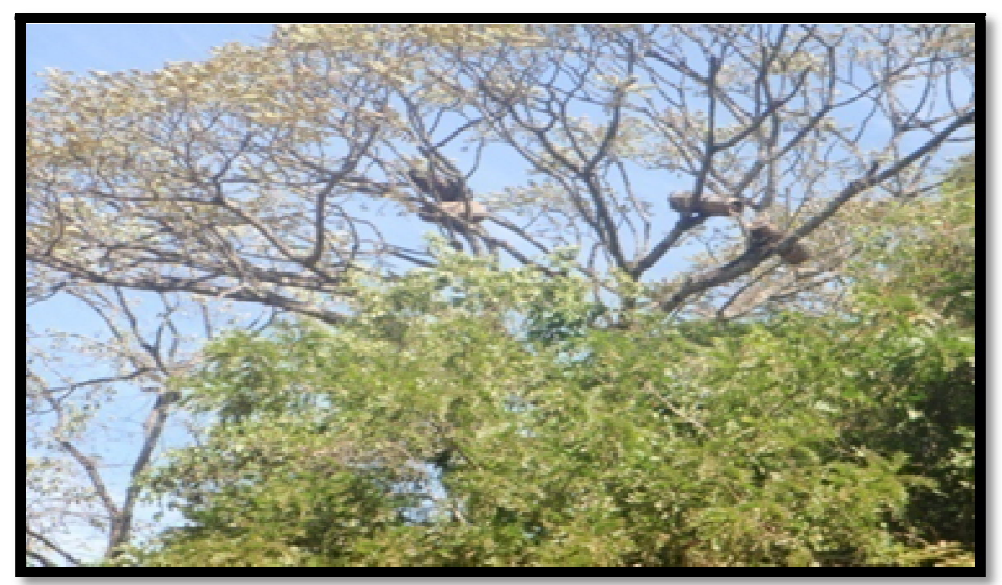

Figure 7: Traditional Beehive 
Guji-Oromo do have two mechanisms of fire using when harvesting honey. Primarily, they use two containers (Okolee). The one serves to hold honey and the other helps to control fire falling dawn from the tree to the ground when the honey collector is on the tree for harvesting. Secondly, additional container is not going to be used but the honey collector should sweep out or clear the dry leaves at the ground of the tree holding beehive. This helps to prevent fire from burning other trees. Then he puts the fire on clear ground. After harvesting is finished, he left the area only after being sure that the fire is extinguished totally.

Generally, this indigenous honey production and harvesting mechanism has contributed a lot for management and conservation of forests since their ancestors to the present generation.

\section{Conclusion}

Guji believe in Waqa, super natural power, the creator who created heaven and earth, trees, grasses, mountains and rivers. In Guji culture, trees are considered as gift from God or Waqa to human beings to manage, conserve and use them properly. In addition, different prayers, marriage ceremonies, meetings, political, economic and other cultural activities are highly attached to trees. There are different religious rituals in different places. Most of the time prayers are performed under trees, forest areas and around rivers.

Guji have deep ecological knowledge and strong relationship with their environment. They believe that if there were no forests, there would be no enough food, honey production, house construction, shade, water for our livestock and human beings. Guji have got detail knowledge about the ecological benefits of trees or forests. They know forests attract rain, source of food for their livestock, place for agricultural activities, and sources of streams, rivers that can be used for drinking water by animals, birds and human beings.

Guji culture has small and major indigenous institutions functioning for forest management and conservation. The smaller are individual house hold (Worra or Ardaa) and village (Olla). While major indigenous institutions are phratries categorized as Uraga, Hoku and Mati and Gada institution that having supreme power in Guji culture. Most of the Woyyuu and ritual places (ardaa jilaa) in Guji culture are found in high land areas where dense forest and abundant trees are found than in low lands. This clearly shows how Guji culture is having strong relationship or dependent on trees and forests.

Almost both women and men do have the same responsibility in their daily life activities like farming, house construction, livestock keeping and others. Child bearing, collection of fuel wood, house construction, fetching water and most of household activities are practiced by women. On the other hand, men are highly engaged in hunting, herding, honey collection and agricultural activities.

Rural economies within the woreda do not comprise a monolithic model of subsistence and commodity economics. Several types of traditional economies are practiced. The basic ones are farming and livestock rearing. There are also other subsistence economic activities such as hunting, gathering, honey production and mining.

Primarily, while preparing farm land, they do not cut down big trees except shrubs and herbs. Livestock rearing is one of the major economic activities of the Guji that highly dependent on forest. They own; cattle, sheep, goats, donkey, mules and horses. The meat, milk and other products of the cattle, sheep and goats are consumed at household level and serve as source of additional income.

One of the strategies is pasture land management that is kept during rainy season and to be used in dry season.There is a seasonal and directional movement/ mobility/ of livestock grazing or transhumance (Godaansa).Shifting utilization of forest resources in livestock reproduction has served to conserve and use forest in sustainable way.

Indigenous forest management strategies are found to be more effective in management, conservation and sustainable use of forests and its products than the government policy. So, in order to stop the destruction of forests and its products, the indigenous knowledge and forest conservation strategies should be promoted by including it in the curriculum of the educational system, and creating awareness to different stakeholders through cultural development offices of the government.

Different government policies and rules that are prepared at regional or national levels for forest management and conservation should include or consider the indigenous customary rules rather than only imposing the government rules on the local people or harmonizing both the government and customary rules of the indigenous people. This is because the indigenous forest management and conservation strategies are proved to be more effective for many generations than the government policy. It would be very important for the management, sustainable utilization and conservation of forests and its products if the government give attention and support for the indigenous institutions so that they become active and functional as the previous time.

\section{References}

i. Dhadacha Gololcha. 2006. The Politico-Legal System of Guji Society of South Ethiopia. DUBAF: Addis Ababa.

ii. Dejene Negassa .2007. "Surviving the State: Resource Tenure and Conflict Dynamics among the Guji-Oromo of Southern Ethiopia. Unpublished PhD. Dissertation. Lexington, Kentucky University.

iii. Taddesse Berisso.2000. "Deforestation and Environmental Degradation in Ethiopia: The case of Jam Jam province." In North East African Studies, Vol.2, No.2, pp. 139-155. USA: Michigan State University Press.

iv. Zewdie Jotte. 2009. "Institutions, Legal Incentives and Conflict in Coffee Forest Use and Conservation: the Case of Yayo Forest in Ilu Abba Bora Zone, Southwest Ethiopia." Unpublished PhD Thesis in Ethiopian Studies, Addis Ababa University. 


\section{Appendix}

\begin{tabular}{|c|c|c|c|}
\hline № & Local Name & Family & Scientific Name \\
\hline 1 & Arabee & Rutaceae & Teclea nobilies Del \\
\hline 2 & Aarsaa & Sapindaceae & Deinbollia kilimandscharica Taub \\
\hline 3 & Ceekata & Fabaceae & Calpurna aurea ( Ait) Benth \\
\hline 4 & Danigola & Tilaiaceae & Triumfeta tomentosa Baj \\
\hline 5 & Darguu & Acanthaceae & Hypostes aristata( Vahl. Roem.\& Schult \\
\hline 6 & Garbii & Fabaceae & Albizia Schimperiana Oliv \\
\hline 7 & Gogodduu & Acanthaceae & Acanthus senni Chiov \\
\hline 8 & Gora-uke & Rutaceae & Toddalia asiatica (L.)Lam \\
\hline 9 & Gudduu & Amaryllidaceae & Scadoxus multiflorus Raf. \\
\hline 10 & Hadaa & Asteraceae & Bidens pilosa L. \\
\hline 11 & Hawuxii & Solanaceae & Nicandra physaloides Gaertn \\
\hline 12 & Hiddii & Solanaceae & Solanum incanum L. \\
\hline 13 & Hoophii & Apocynaceae & Landolphia buchananii Stapf \\
\hline 14 & Kayo & Commelinaceae & Commelina benghalensis L. \\
\hline 15 & Qundhii & Cypperaceae & Cyperus bulbosus Vahl. \\
\hline 16 & Mararee & Euphorbiaceae & Macaranga capensia Sim \\
\hline 17 & Miqee & Rubaiceae & Rhytigyna neglecta Robyns \\
\hline 18 & Sakarroo & Meliaceae & Lepidotrichilla volkensii Leroy \\
\hline 19 & Sarajjii & Spindaceae & Allophylus abyssinicus Radlk \\
\hline 20 & Sesiqoo & Asteraceae & Laggera crispate He[[er\& Wood \\
\hline 21 & Xibirroo & Melianthaceae & Bersama abyssinica Fresen \\
\hline 22 & Xixxixaa & Rhizphoraceae & Cassipourea malosana Alston \\
\hline 23 & Daafaa & Poaceae & Oplismenus hirtellus (L.) p.Beauv \\
\hline 24 & Wolichuu & Oleaceae & Chionanthus mildbraedii stearn \\
\hline 25 & Birbissaa & Podocarpaceae & Podocarpus falcatus \\
\hline 26 & Uddeessaa & Verbenaceae & Prmna schimperi \\
\hline 27 & Mokkonniisa & Euphorbiaceae & Croton Macrostachyus \\
\hline 28 & Gagamaa & Oleaceae & Olea capensis \\
\hline 29 & Motoqoomaa & Ulmaceae & Celtis Africana \\
\hline 30 & Mararee & Euphorbeaceae & Macranga \\
\hline 31 & Baddessaa & Myrtaceae & Syzygium guineese \\
\hline 32 & Buna Boyyee & Rubiaceae & Galiniera saxifrga \\
\hline 33 & Dhaadhatuu & Fabaceae & Millettiaferruginea \\
\hline 34 & Dareersa & Luaraceae & Ocotea kenyensi \\
\hline 35 & Dikicha & Vitaceae & Rhoicissustridentata \\
\hline 36 & Anuunuu & Meliaceae & Ekebergia capensis \\
\hline 37 & Ebicha & Asteraceae & Vernoniaamygdalina \\
\hline 38 & Gaalloo & Rubiaceae & Psydraxschimpriana \\
\hline 39 & Gatamee & Araliaceae & Schefflera abyssinica \\
\hline 40 & Reejjii & Solanaceae & Discopodium penninervum \\
\hline 41 & Saawwaa & Oleaceae & Olea welwitschii \\
\hline 42 & Sisaa & Fabaceae & Albizia jummifera \\
\hline 43 & Talaa & Araliaceae & Poliyscias fulva \\
\hline 44 & Xilloo & Pittosporaceae & Pittosporum viridiflorum \\
\hline 45 & Uraagaa & Boraginaceae & Ehretia cymosa \\
\hline 46 & Worqoo & Dracaenaceae & Dracaena steudneri \\
\hline 47 & Gudubaa & Sapotaceae & Pouteriana dolfi-friedricii \\
\hline 48 & Hadaammaa & Euphorbiaceae & Euphorbia abyssinica \\
\hline 49 & Hadheessa & Rutaceae & Teclea nobilis \\
\hline 50 & Harangamaa & Capparidaceae & Capparis tomentosa \\
\hline 51 & Haranjii & Phytolaccaceae & Phytolacca dodecandra \\
\hline 52 & Harruu & Moraceae & Ficus sur \\
\hline 53 & Hidda woraabessaa & Solanaceae & Pullinia piñata \\
\hline 54 & Kom'olcha & Celastraceae & Mytenus ardutifolia \\
\hline 55 & Miqee & Rubiaceae & Rhytigyna neglecta \\
\hline 53 & Woddeessa & & Cordia adryssinica \\
\hline 57 & Odaa & & \\
\hline 58 & Qiाxaa & & \\
\hline
\end{tabular}

Table 1: Some of the Scientific Names of Major Species of Trees, Shrubs and Herbs in Guji Girja Land Source: Key Informants 